\title{
SOIL PHOSPHORUS AVAILABILITY AND SOYBEAN RESPONSE TO PHOSPHORUS STARTER FERTILIZER ${ }^{(1)}$
}

\author{
Ciro Antonio Rosolem ${ }^{(2)} \&$ Alexandre Merlin ${ }^{(3)}$
}

\begin{abstract}
SUMMARY
Phosphorus fixation in tropical soils may decrease under no-till. In this case, $P$ fertilizer could be surface-spread, which would improve farm operations by decreasing the time spend in reloading the planter with fertilizers. In the long term, less soluble $P$ sources could be viable. In this experiment, the effect of surface-broadcast $\mathbf{P}$ fertilization with both soluble and reactive phosphates on soil $\mathbf{P}$ forms and availability to soybean was studied with or without fertilization with soluble $P$ in the planting furrow in a long-term experiment in which soybean was grown in rotation with Ruzigrass (Brachiaria ruziziensis). No $P$ or $80 \mathrm{~kg} \mathrm{ha}^{-1}$ of $\mathrm{P}_{2} \mathrm{O}_{5}$ in the form of triple superphosphate or Arad reactive rock phosphate was applied on the surface of a soil with variable $P$ fertilization history. Soil samples were taken to a depth of $60 \mathrm{~cm}$ and soil $P$ was fractionated. Soybean was grown with 0,30 , and $60 \mathrm{~kg} \mathrm{ha}^{-1}$ of $\mathrm{P}_{2} \mathrm{O}_{5}$ in the form of triple phosphate applied in the seed furrow. Both fertilizers applied increased available $P$ in the uppermost soil layers and the moderately labile organic and inorganic forms of $P$ in the soil profile, probably as result of root decay. Soybean responded to phosphates applied on the soil surface or in the seed furrow; however, application of soluble $P$ in the seed furrow should not be discarded. In tropical soils with a history of $\mathbf{P}$ fertilization, soluble $P$ sources may be substituted for natural reactive phosphates broadcast on the surface. The planting operation may be facilitated through reduction in the rate of $\mathrm{P}$ applied in the planting furrow in relation to the rates currently applied.
\end{abstract}

Index terms: fertilization, Brachiaria ruziziensis, phosphates, soil fertility.

(1) Received for publication on October 14, 2013 and approved on July $1^{\text {st }}, 2014$.

(2) Full Professor, Departamento de Produção Vegetal, Faculdade de Ciências Agronômicas, Universidade Estadual Paulista. Rua José Barbosa de Barros, 1780. CEP 18610-307 Botucatu (SP), Brazil. Fellowship Holder 1A of the CNPq. E-mail: rosolem@fca.unesp.br

(3) Field Production Supervisor, Monsanto. Rua Eduardo Oliveira, 940. CEP 38400-174 Uberlândia (MG), Brazil. E-mail: alexandre.merlin@monsanto.com 


\title{
RESUMO: DISPONIBILIDADE DE FÓSFORO NO SOLO E RESPOSTA DA SOJA AO FERTILIZANTE APLICADO NO SULCO DE SEMEADURA
}

\begin{abstract}
A fixação de fósforo em solos tropicais pode ser diminuida sob plantio direto. Nesse caso, o fertilizante poderia ser aplicado na superfície do solo, o que melhoraria o rendimento operacional pela diminuição do reabastecimento da semeadora com fertilizantes. Em longo prazo, fontes de $P$ menos solúveis poderiam ser viáveis. Nesse experimento, o efeito da aplicação de $P$ em superfície, tanto o fosfato solúvel como reativo, sobre as formas de $P$ no solo e a disponibilidade para a soja foram estudados em combinação com a aplicação de P solúvel nos sulcos de semeadura, em um experimento de longa duração, onde a soja foi cultivada em rotação com braquiária (Brachiaria ruziziensis). Fertilizantes fosfatados foram aplicados na superficie de um solo com histórico de aplicações de $P$, nas doses 0,0 e $80,0 \mathrm{~kg} \mathrm{ha} \mathrm{g}^{-1}$, na forma de superfosfato triplo ou fosfato Arad. Amostras de solo foram tomadas até $60 \mathrm{~cm}$ de profundidade, e o P do solo foi fracionado. A soja foi cultivada com 0 , 30 e $60 \mathrm{~kg} \mathrm{ha} \mathrm{h}^{-1}$ de $\mathrm{P}_{2} \mathrm{O}_{5}$ como superfosfato triplo aplicado no sulco da semente. Ambos os fertilizantes aplicados em superficie aumentaram o $P$ disponível nas camadas superiores do solo e as formas moderadamente lábeis orgânica e inorgânica de P no perfil do solo, provavelmente como resultado do apodrecimento radicular. A soja respondeu aos fosfatos aplicados na superfície do solo ou no sulco de semeadura; no entanto, a aplicação de $P$ solúvel no sulco não deve ser descartada. Em solos tropicais, com uma história de fertilização fosfatada, fontes de $P$ solúveis podem ser substituidas por fosfatos naturais reativos aplicados à superfície do solo. A operação de semeadura pode ser agilizada pela redução da taxa de P aplicada ao sulco da sementeira, em relação às doses que são empregadas atualmente.
\end{abstract}

Termos de indexação: adubação, Brachiaria ruziziensis, fosfatos, fertilidade do solo.

\section{INTRODUCTION}

Tropical soils are deficient in $\mathrm{P}$ due the poor parent material and strong fixation of $\mathrm{P}$ to colloids. Less than $0.1 \%$ of the total is found in solution, limiting biomass productivity (Novais \& Smyth, 1999) and adequate levels of available $\mathrm{P}$ in the soil are essential for crop production. Therefore, phosphate fertilization is paramount in these soils.

Growing cover crops in the winter or spring can affect $\mathrm{P}$ fertilizer efficiency in tropical agricultural systems. The accumulation of $\mathrm{P}$ in plant tissue may reduce losses that occur due to rainfall and fixation, and this nutrient may be available later as plant residues decay (Pavinato \& Rosolem, 2008). Based on this concept, the use of less soluble $\mathrm{P}$ sources in systems under no-till may be technically and economically viable, as long as this is associated with cover crops which are efficient in uptake and cycling of less labile $\mathrm{P}$ forms. Although reactive rock phosphates such as Arad and Gafsa are cheaper than soluble phosphates, in the first year, yields are lower than those observed with soluble phosphates (Horowitz $\&$ Meurer, 2004). The use of cover crops efficient in $\mathrm{P}$ cycling, such as black oat (Avena sativa), velvetbean (Mucuna pruriens), common vetch (Vicia sativa) and lupins (Lupinus albus), has been studied, as well as plants of the Brachiaria genus (Silva et al., 2003), but results on $\mathrm{P}$ cycling potential are not well known yet. Phosphate fertilization applied to finger millet (Eleusine coracana) led to higher phytomass production, but there was no effect on soybean yield when it was grown in rotation (Francisco et al., 2007). Increases in $\mathrm{P}$ availability have been observed under no-till because organic acids or soluble organic C stemming from organic matter breakdown compete for the soil colloid adsorption sites (Novais \& Smyth, 1999; Rheinheimer et al., 2000). Nevertheless, increases in soil $\mathrm{P}$ availability with the addition of plant residues may be, in large part, attributed to a greater mineralization of $\mathrm{P}$ from the added organic material itself, and not the competitive roles of soluble organic $\mathrm{C}$ and $\mathrm{P}$ for adsorption sites in the soil. In fact, the inorganic $\mathrm{P}(\mathrm{Pi})$ released from plant residues occupies part of the adsorption sites, which results in an apparent decrease in P adsorption (Erich et al., 2002).

Effects of phosphate fertilization management associated with crop rotations on soil $\mathrm{P}$ availability can be evaluated using sequential fractionation of soil P, as developed by Hedley et al. (1982). Through this method, it is possible to evaluate alterations in different soil $\mathrm{P}$ fractions, such as available $\mathrm{P}$ (resin), moderately labile $\mathrm{P}\left(\mathrm{NaHCO}_{3}\right), \mathrm{Fe}$ and $\mathrm{Al}$ bound $\mathrm{P}$ $(\mathrm{NaOH})$, Ca bound $\mathrm{P}(\mathrm{HCl})$, total $\mathrm{Pi}$ (inorganic $\mathrm{P}$ ) and total Po (organic soil $\mathrm{P}$ pools).

The combined effects of plant residue and longterm $\mathrm{P}$ fertilization on soil $\mathrm{P}$ forms and $\mathrm{P}$ availability within the soil profile are still little known. Thus, the present study aimed at assessing soil $\mathrm{P}$ dynamics and availability to soybeans grown in rotation with cover crops in a long-term experiment under no-till, with or without soluble $\mathrm{P}$ fertilization in the seed furrow. 


\section{MATERIALS AND METHODS}

The experiment was carried out in Botucatu, São Paulo, Brazil, $22^{\circ} 51^{\prime} \mathrm{S}, 48^{\circ} 26^{\prime} \mathrm{W}$ and altitude of $840 \mathrm{~m}$. The soil of the experimental area is a Rhodic Hapludox (Soil Survey Staff, 2010), sandy loam with $670 \mathrm{~g} \mathrm{~kg}^{-1}$ of sand and $210 \mathrm{~g} \mathrm{~kg}^{-1}$ of clay. Selected chemical characteristics of the soil are shown in table 1 . The field had been cropped under no-till and crop rotation for five years (Table 2). In the first and third years the experiment received 0 or $80 \mathrm{~kg} \mathrm{ha}^{-1}$ of $\mathrm{P}_{2} \mathrm{O}_{5}$ surface-broadcast as triple superphosphate (TSP) or Arad reactive rock phosphate (ARP). A total of $200 \mathrm{~kg} \mathrm{ha}^{-1}$ of $\mathrm{P}_{2} \mathrm{O}_{5}$ had been applied in soybean furrows in five years, totaling $200 \mathrm{~kg} \mathrm{ha}^{-1}$ (without surface broadcast) and $360 \mathrm{~kg} \mathrm{ha}^{-1}$ (with surface broadcast) of $\mathrm{P}_{2} \mathrm{O}_{5}$. This particular experiment was conducted during the sixth cropping season, when 0 and $80 \mathrm{~kg} \mathrm{ha}-1$ of $\mathrm{P}_{2} \mathrm{O}_{5}$ (calculated as the total $\mathrm{P}$ contained in each fertilizer) were surface broadcast as TSP (soluble) and natural ARP (reactive) to the same plots that had previously received the fertilizers. The TSP had $179 \mathrm{~g} \mathrm{~kg}^{-1}$ of total P, $92 \mathrm{~g} \mathrm{~kg}^{-1}$ of $\mathrm{Ca}$, and $10 \mathrm{~g} \mathrm{~kg}^{-1}$ of S. The ARP showed $139 \mathrm{~g} \mathrm{~kg}^{-1}$ of $\mathrm{P}$, $264 \mathrm{~g} \mathrm{~kg}^{-1}$ of $\mathrm{Ca}$, and $10 \mathrm{~g} \mathrm{~kg}^{-1}$ of S. After P application, ruzigrass (Brachiaria ruziziensis) was planted using $30 \mathrm{~kg} \mathrm{ha}^{-1}$ of seeds ( $32 \%$ of viable seeds) and desiccated 75 days after emergence (DAE) with glyphosate (phosphonomethyl glycine) at $2.88 \mathrm{~kg} \mathrm{ha}^{-1}$ (active ingredient).

Ruzigrass residues were sampled using a $0.25 \mathrm{x}$ $0.25 \mathrm{~m}$ wooden square. Three sup-samples were taken from each plot, combined, dryed, ground and wet digested for nutrient analysis.

After ruzigrass desiccation, six soil samples were taken randomly from each plot with an auger at five depths (0-5, 5-10, 10-20, 20-40, and 40-60 cm) and combined into one for each soil depth for analysis. Soil acidity (in calcium chloride) and organic matter (Walkey-Black method) were determined. Fractionation of soil $\mathrm{P}$ was carried out according to Hedley et al. (1982), with modifications proposed by Condron et al. (1985). Labile inorganic $P$ was extracted with anion exchange resin (General Electric Water Systems Membrane Anionic Resin 204SZRA88091668). Labile inorganic and organic $\mathrm{P}$ were extracted with $0.5 \mathrm{~mol} \mathrm{~L}^{-1} \mathrm{NaHCO}_{3}$, and $\mathrm{P}$ bound to $\mathrm{Fe}$ and $\mathrm{Al}$ oxides (moderately labile inorganic and organic $\mathrm{P}$ ) were extracted with $0.1 \mathrm{~mol} \mathrm{~L}^{-1} \mathrm{NaOH}$. Calcium bound $\mathrm{P}$ was extracted with $1.0 \mathrm{~mol} \mathrm{~L}^{-1} \mathrm{HCl}$.

Table 1. Selected chemical characteristics of the soil of the experimental area at the beginning of the experiment (March 2006)

\begin{tabular}{|c|c|c|c|c|c|c|c|c|c|c|}
\hline Treatment & Depth & $\mathrm{pH}\left(\mathrm{CaCl}_{2}\right)$ & $\mathrm{OM}^{(1)}$ & $P_{\text {resin }}{ }^{(2)}$ & $\mathrm{H}+\mathrm{Al}$ & $\mathbf{K}$ & $\mathbf{C a}$ & Mg & $\mathrm{CEC}^{(3)}$ & $\mathrm{BS}^{(4)}$ \\
\hline & $\mathrm{cm}$ & & $\mathrm{g} \mathrm{dm}^{-3}$ & $\mathrm{mg} \mathrm{dm} \mathrm{m}^{-3}$ & & 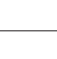 & $\mathrm{mol}_{\mathrm{c}} \mathrm{d}$ & & & $\%$ \\
\hline \multirow[t]{5}{*}{$0 \mathrm{~kg}$ of $\mathrm{P}_{2} \mathrm{O}_{5} \mathrm{ha}^{-1}$} & $0-5$ & 4.9 & 22.5 & 20.2 & 26.9 & 1.4 & 19.2 & 7.4 & 54.8 & 50.9 \\
\hline & $5-10$ & 4.7 & 20.3 & 14.1 & 30.4 & 0.9 & 13.8 & 5.3 & 50.4 & 39.6 \\
\hline & $10-20$ & 4.5 & 18.9 & 8.5 & 32.6 & 0.7 & 9.9 & 3.8 & 47.0 & 30.5 \\
\hline & $20-40$ & 4.3 & 18.0 & 5.6 & 40.3 & 0.5 & 6.4 & 3.3 & 50.6 & 20.2 \\
\hline & $40-60$ & 4.2 & 17.6 & 4.2 & 49.8 & 0.4 & 3.8 & 2.5 & 56.5 & 11.8 \\
\hline \multirow{5}{*}{$\begin{array}{l}80 \mathrm{~kg} \text { of } \mathrm{P}_{2} \mathrm{O}_{5} \mathrm{ha}^{-1} \\
\text { reactive phosphate } \\
\text { (Arad phosphate) }\end{array}$} & $0-5$ & 5.1 & 23.7 & 27.0 & 25.8 & 1.7 & 15.4 & 7.6 & 50.4 & 48.8 \\
\hline & $5-10$ & 4.8 & 20.3 & 13.7 & 29.6 & 0.8 & 10.6 & 4.6 & 45.6 & 35.0 \\
\hline & $10-20$ & 4.7 & 18.4 & 9.6 & 30.9 & 0.7 & 9.1 & 3.2 & 43.9 & 29.6 \\
\hline & $20-40$ & 4.4 & 17.3 & 6.1 & 38.4 & 0.6 & 6.4 & 3.1 & 48.6 & 20.8 \\
\hline & $40-60$ & 4.2 & 16.8 & 4.5 & 48.7 & 0.4 & 4.9 & 2.5 & 56.5 & 13.8 \\
\hline \multirow{5}{*}{$\begin{array}{l}80 \mathrm{~kg} \text { of } \mathrm{P}_{2} \mathrm{O}_{5} \text { ha }^{-1} \\
\text { Soluble phosphate } \\
\text { (Triple superphosphate) }\end{array}$} & $0-5$ & 5.0 & 24.1 & 26.4 & 25.5 & 1.3 & 17.6 & 7.4 & 51.8 & 50.7 \\
\hline & $5-10$ & 4.7 & 20.6 & 13.3 & 29.5 & 1.1 & 12.5 & 5.1 & 48.3 & 38.8 \\
\hline & $10-20$ & 4.4 & 18.5 & 9.3 & 30.0 & 0.8 & 10.0 & 3.5 & 44.3 & 32.1 \\
\hline & $20-40$ & 4.4 & 17.6 & 5.6 & 39.5 & 0.7 & 6.1 & 3.1 & 49.3 & 20.2 \\
\hline & $40-60$ & 4.2 & 17.8 & 4.2 & 50.0 & 0.5 & 4.9 & 2.5 & 57.8 & 13.4 \\
\hline
\end{tabular}

(1) OM: organic matter; ${ }^{(2)}$ Pearl resin proposed by Raij et al. $(2001) ;{ }^{(3)}$ CEC: cation exchange capacity; ${ }^{(4)}$ BS: base saturation.

Table 2. Crop rotation system at the experimental site

\begin{tabular}{lcccccc}
\hline \multirow{2}{*}{ Crop season } & \multicolumn{4}{c}{ Crop year } \\
\cline { 2 - 6 } & $\mathbf{1}$ & $\mathbf{2}$ & $\mathbf{3}$ & $\mathbf{4}$ & $\mathbf{6}$ \\
\hline Fall-winter & Triticale & Black oat & Triticale & Black oat & Triticale & Ruzigrass \\
Spring & Pearl millet & Pearl millet & Pearl millet & Pearl millet & Pearl millet & Ruzigrass \\
Summer & Soybean & Soybean & Soybean & Soybean & Soybean & Soybean \\
\hline
\end{tabular}


Occluded inorganic and organic $\mathrm{P}$ from soil micro aggregates (non-labile $\mathrm{P}$ ) were extracted with 0.5 mol L ${ }^{-1} \mathrm{NaOH}$. Residual $\mathrm{P}$ was extracted with $\mathrm{H}_{2} \mathrm{SO}_{4}$, and total organic $\mathrm{P}$ was calculated as the difference between results from unburned and burned (electric oven at $550{ }^{\circ} \mathrm{C}$ for $2 \mathrm{~h}$ ) samples, as in Olsen \& Sommers (1982). Phosphorus was determined by colorimetry, as in Murphy \& Riley (1962). All samples were analyzed in triplicate.

Upon ruzigrass desiccation, the soybean cultivar BRS 184 was mechanically planted over the standing cover crop residues in rows $0.45 \mathrm{~m}$ apart with a population of 320,000 plants per ha. The triple superphosphate was applied to the seed furrows at 0 , 30 , and $60 \mathrm{~kg} \mathrm{ha}^{-1}$ of $\mathrm{P}_{2} \mathrm{O}_{5}$. After planting, $80 \mathrm{~kg} \mathrm{ha}^{-1}$ of $\mathrm{K}_{2} \mathrm{O}$ was broadcast as potassium chloride to all plots. Soybean was harvested at 128 DAE. At R2 (Fehr et al., 1971), 30 of the most recently mature soybean leaves were sampled per plot, dried at $60^{\circ} \mathrm{C}$ for $48 \mathrm{~h}$, and ground for $\mathrm{P}$ analysis, as described for ruzigrass residues.

For soil samples, a completely randomized block experimental design was used with three treatments and 12 replications (four replications plus the plots corresponding to soybean fertilization). Data for each soil depth were analyzed separately. For soybean, the experimental design was a split plot ( $\mathrm{P}$ initial treatments in plots $\times$ soybean fertilization in split plots) with four replications. Split-plots were $5.0 \times 8.0 \mathrm{~m}$, and blocks were set up $9.0 \mathrm{~m}$ apart from each other to allow machine traffic. The results were subjected to ANOVA (SAS, 2001), and the means were compared by LSD $(\mathrm{p}<0.05)$.

\section{RESULTS}

The average dry matter yield of ruzigrass was $4,644 \mathrm{~kg} \mathrm{ha}^{-1}$, and the average $\mathrm{P}$ content in the tissue was $2.1 \mathrm{~g} \mathrm{~kg}^{-1}$, with no significant differences between treatments. The average contents of $\mathrm{N}, \mathrm{K}, \mathrm{Ca}$, and $\mathrm{Mg}$ in plant tissue were 12.7, 18.0, 6.3, and $4.3 \mathrm{~g} \mathrm{~kg}^{-1}$, respectively, without differences due to $\mathrm{P}$ fertilization. These nutrient contents are within the adequate range, showing that there was no nutrient deficiency for ruzigrass during the experiment.

Phosphate application on the soil surface increased labile inorganic $\mathrm{P}$ levels (extracted with resin) down to the $10-20 \mathrm{~cm}$ soil layer (Figure 1a), but the increase was higher in the $0-10 \mathrm{~cm}$ layer with TSP. The inorganic labile $\mathrm{P}$ fraction extracted by $0.5 \mathrm{~mol} \mathrm{~L}^{-1}$ $\mathrm{NaHCO}_{3}$ was higher in the uppermost soil layers, but was not affected by $\mathrm{P}$ fertilization (Figure 1b). Inorganic $\mathrm{P}$ bound to $\mathrm{Fe}$ and $\mathrm{Al}$ increased down to the 20-40 cm soil layer (Figure 1c), and was higher for TSP.

The inorganic Ca-bound $\mathrm{P}$ also increased in layers close to the soil surface $(0-10 \mathrm{~cm})$, with no effect deeper in the soil profile (Figure 2a), and the soil $\mathrm{P}$ contents with ARP were even higher than with TSP in the $0-5 \mathrm{~cm}$ soil layer. Inorganic $\mathrm{P}$ extracted with 0.5 mol L ${ }^{-1} \mathrm{NaOH}$, a non-labile $\mathrm{P}$ form, was increased by ARP down to $10-20 \mathrm{~cm}$ in the soil (Figure $2 \mathrm{~b}$ ).

Residual inorganic $\mathrm{P}$ was not affected by $\mathrm{P}$ fertilizers in the soil profile (Figure 3a), but the total inorganic $\mathrm{P}$ increased in the $0-5 \mathrm{~cm}$ soil layer

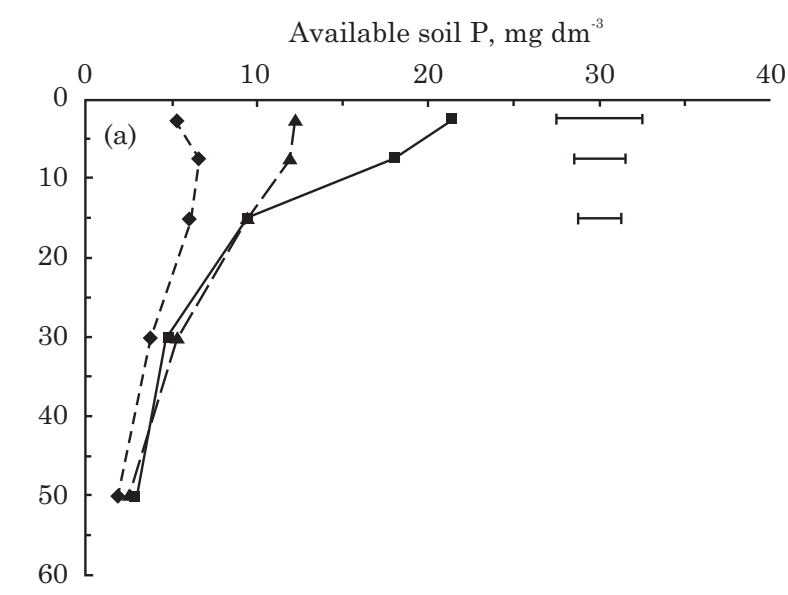

Inorganic labile $\mathrm{P}, \mathrm{mg} \mathrm{dm}^{-3}$
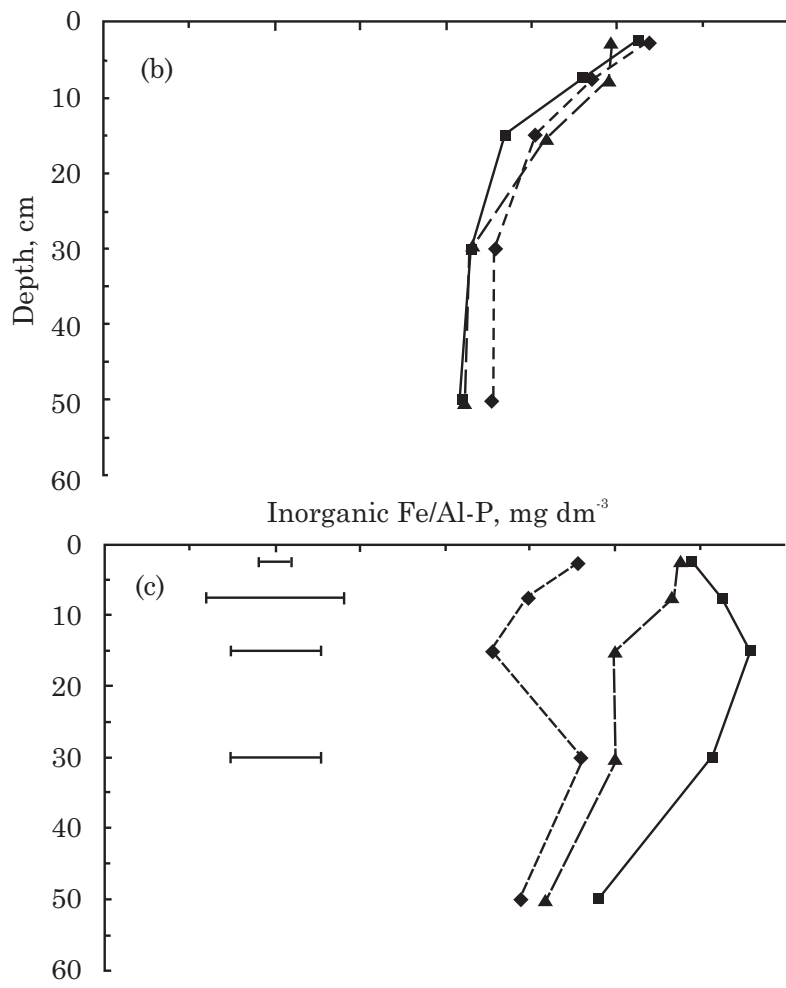

Figure 1. Available, inorganic labile, and Fe/Al-bound soil $P$ as affected by surface-broadcast $P$ fertilizers and depth. (a) $\mathbf{P}$ extracted with membrane resin; (b) Inorganic labile P; (c) Inorganic $P$ bound to iron and aluminum. Dotted line - No P; dashed line - natural reactive Arad phosphate; solid line - triple superphosphate. Horizontal bars show LSD $(p<0.05)$ and compare treatments within each soil depth. 
Inorganic Ca- $\mathrm{P}, \mathrm{mg} \mathrm{dm}^{-3}$

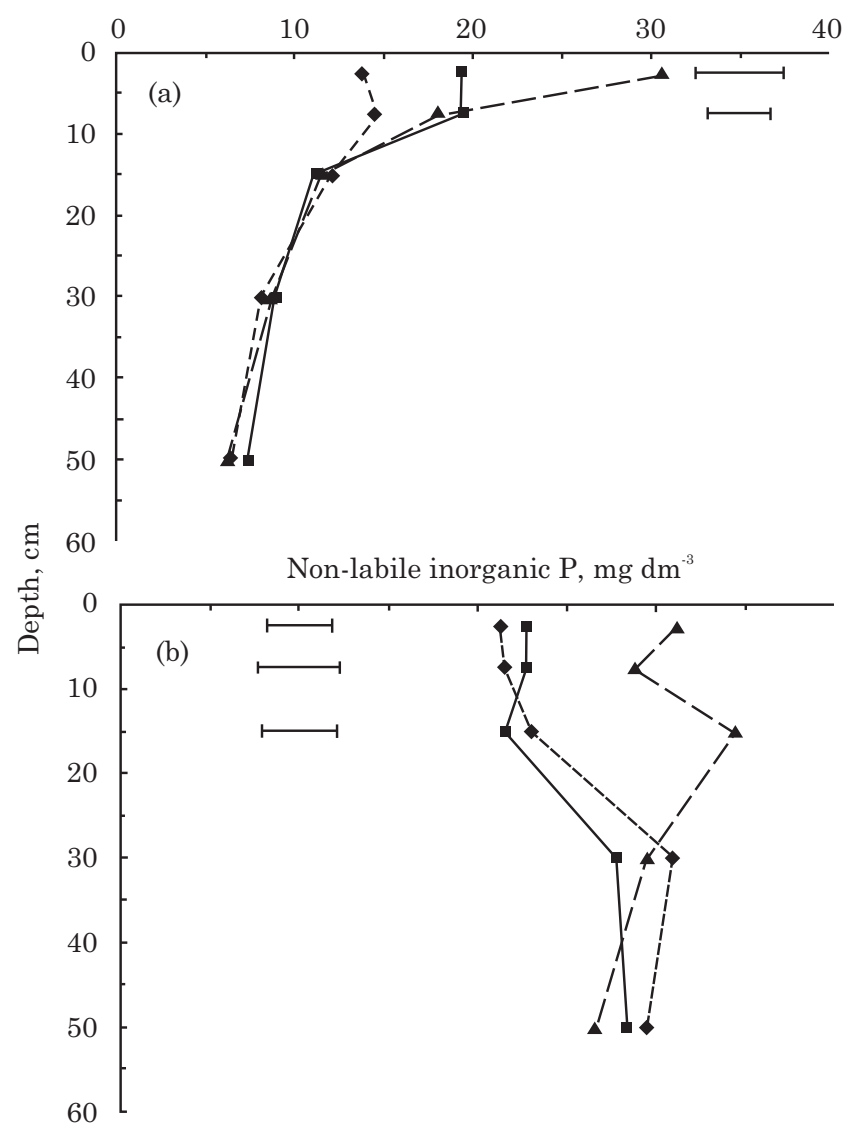

Figure 2. Inorganic Ca-bound and non-labile inorganic soil $P$ as affected by surfacebroadcast $P$ fertilizers and depth. (a) Ca-bound inorganic P; (b) Non-labile inorganic P. Dotted line - No P; dashed line - natural reactive Arad phosphate; solid line - triple superphosphate. Horizontal bars show LSD $(p<0.05)$ and compare treatments within each soil depth.

irrespective of $\mathrm{P}$ application, and down to the $40-60 \mathrm{~cm}$ layer with $\mathrm{P}$ fertilization, irrespective of the $\mathrm{P}$ source (Figure 2b).

The organic labile $\mathrm{P}$ was higher in the uppermost soil layer, irrespective of $\mathrm{P}$ fertilization, but there was no effect of fertilizers (Figure 4a). However, the organic Fe/Al-bound $\mathrm{P}$ extracted with $0.1 \mathrm{~mol} \mathrm{~L}^{-1}$ $\mathrm{NaOH}$ e was higher under phosphate fertilization down to the $20-40 \mathrm{~cm}$ layer (Figure $4 \mathrm{~b}$ ).

High levels of organic non-labile $\mathrm{P}$ extracted with $\mathrm{NaOH}$ were observed at $0-5 \mathrm{~cm}$ (Figure $5 \mathrm{a}$ ), but no change was observed in deeper layers. Total organic $\mathrm{P}$ only responded to $\mathrm{P}$ fertilization in the $0-5 \mathrm{~cm}$ soil layer, and was higher with the use of ARP (Figure 5b).

Average soybean yields were higher with surfacebroadcast $\mathrm{P}$ fertilization, irrespective of the $\mathrm{P}$ source, but the response depended on $\mathrm{P}$ application in the furrow (Figure 6a). When no $\mathrm{P}$ was broadcast, soybean responded to furrow application of TSP up to $26 \mathrm{~kg} \mathrm{ha}^{-1}$,

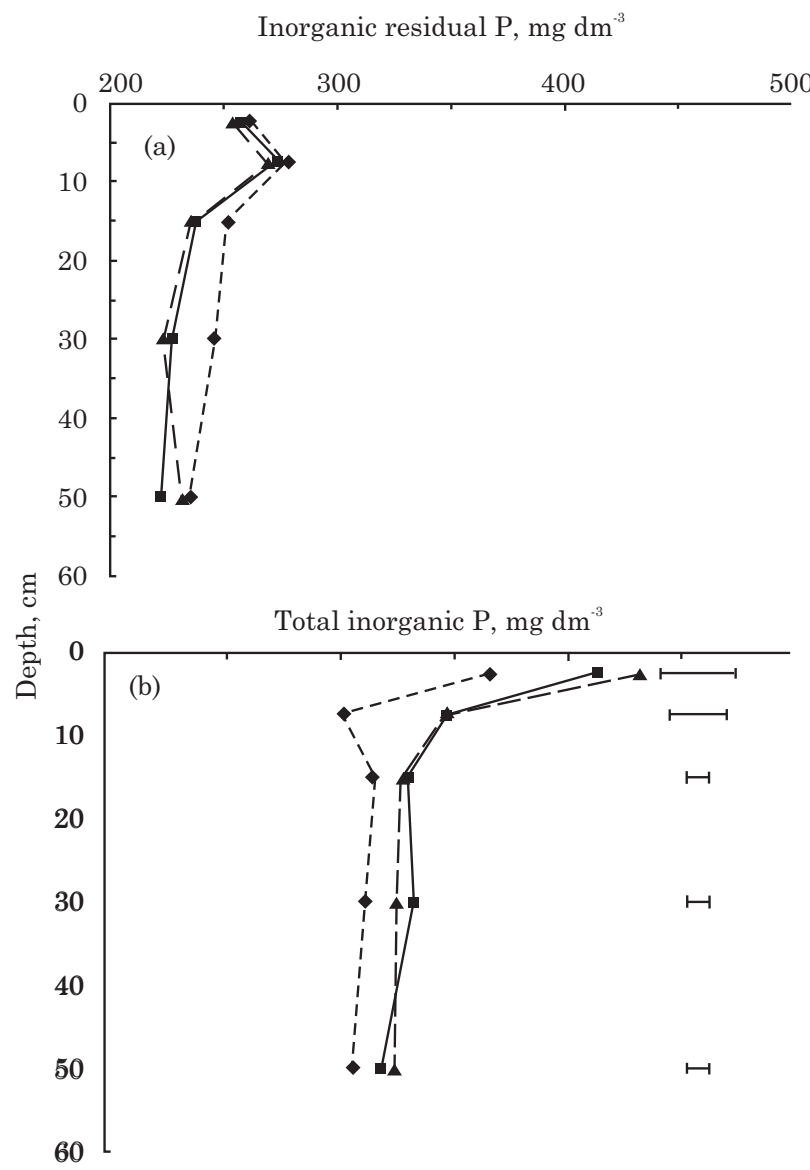

Figure 3. Residual and total inorganic soil $P$ in the soil profile as affected by surface- broadcast $P$ fertilizers. (a) Inorganic residual P; (b) Total inorganic P. Dotted line - No P; dashed line natural reactive Arad phosphate; solid line triple superphosphate. Horizontal bars show LSD $(\mathrm{P}<0.05)$ and compare treatments within each soil depth.

but $\mathrm{P}$ addition either broadcast or in the furrow overcame soybean yield differences. Phosphorus contents in soybean leaves were below the threshold levels (2.0-5.0 $\mathrm{g} \mathrm{kg}^{-1}$ ) when no $\mathrm{P}$ was broadcast, but were higher when $\mathrm{P}$ was broadcast, and at least 13 $\mathrm{kg} \mathrm{ha}^{-1}$ was applied in the furrows (Figure 6b).

\section{DISCUSSION}

In the present study, the lower initial resinextracted $\mathrm{P}$ level (on average $5.0 \mathrm{mg} \mathrm{dm}^{-3}$ ) was sufficient for ruzigrass growth and development, since there was no response either in dry matter yields or plant tissue P contents. Differences between natural and soluble phosphate sources have not been observed in grasses of the genus Brachiaria (Horowitz \& Meurer, 2004) and, according to Garcia (2004), plants of this genus are well adapted to low natural fertility 


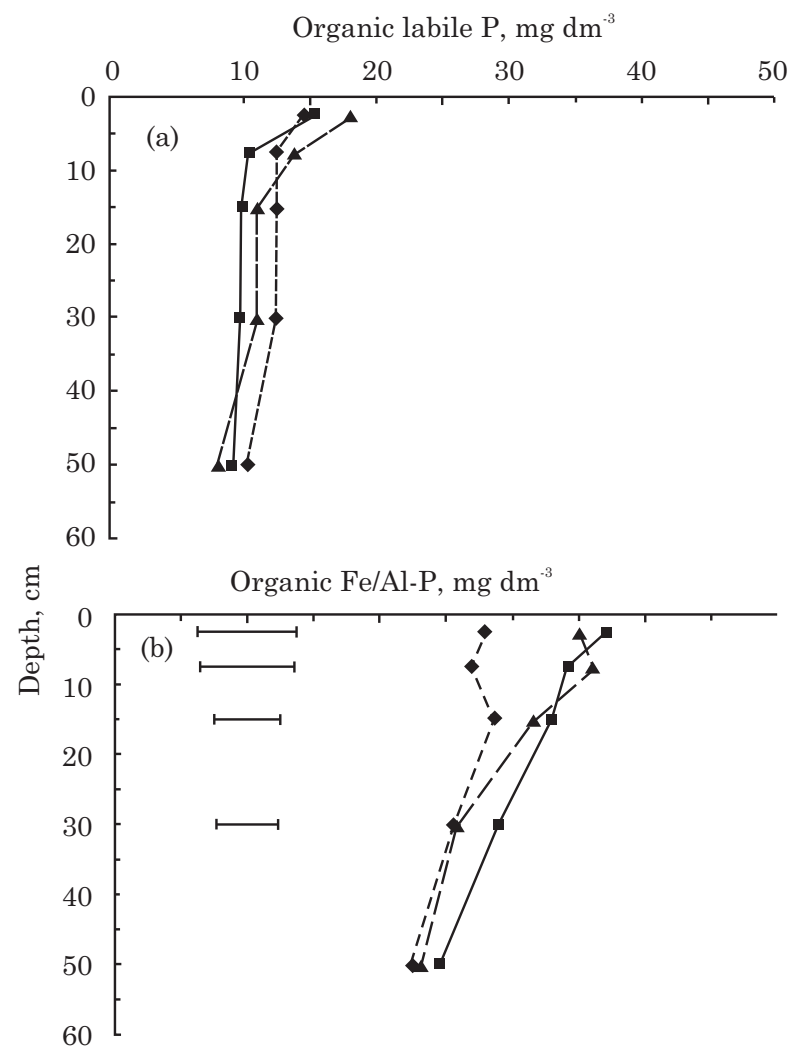

Figure 4. Organic labile and Fe/Al-bound soil $P$ in the soil profile as affected by surface- broadcast P fertilizers. (a) Organic labile P; (b) Organic Fe/Al-bound P. Dotted line - No P; dashed line natural reactive Arad phosphate; solid line triple superphosphate. Horizontal bars show LSD $(p<0.05)$, and compare treatments within each soil depth.

soils. The high adaptation to low fertility and low response to $\mathrm{P}$ make this species a choice for straw production under no-till using cheaper $\mathrm{P}$ fertilizers.

The predominance of $\mathrm{Fe}$ - and $\mathrm{Al}$-bound $\mathrm{P}$ was expected, as well as a decrease in P lability due to soil acidity $(\mathrm{pH}$ around 5.0, Table 1) in the present experiment since the highest $P$ availability is usually found at $\mathrm{pH}$ around 6.5. A decrease in labile $\mathrm{P}$ was observed in the soil profile, and this effect was significant at all depths (Figure 1). The effects observed on labile $\mathrm{P}$ forms after ruzigrass were similar to those found by Olibone \& Rosolem (2010), who reported a better $\mathrm{P}$ distribution in the soil profile after soybean. Galvani et al. (2008) also found higher P levels in soil layers from the 5-10 cm depth after TSP surface application. Pearse et al. (2006) observed a significant increase in soil labile $\mathrm{P}$ down to $10 \mathrm{~cm}$ and an increasing tendency down to $30 \mathrm{~cm}$ with $\mathrm{P}$ application on the soil surface.

Phosphate fertilization affected the soil inorganic $\mathrm{P}$ fraction (extracted with $0.5 \mathrm{~mol} \mathrm{~L}^{-1} \mathrm{NaHCO}_{3}$ ), and soluble sources led to higher increases compared with natural or reactive phosphates (Dobermann et al.,

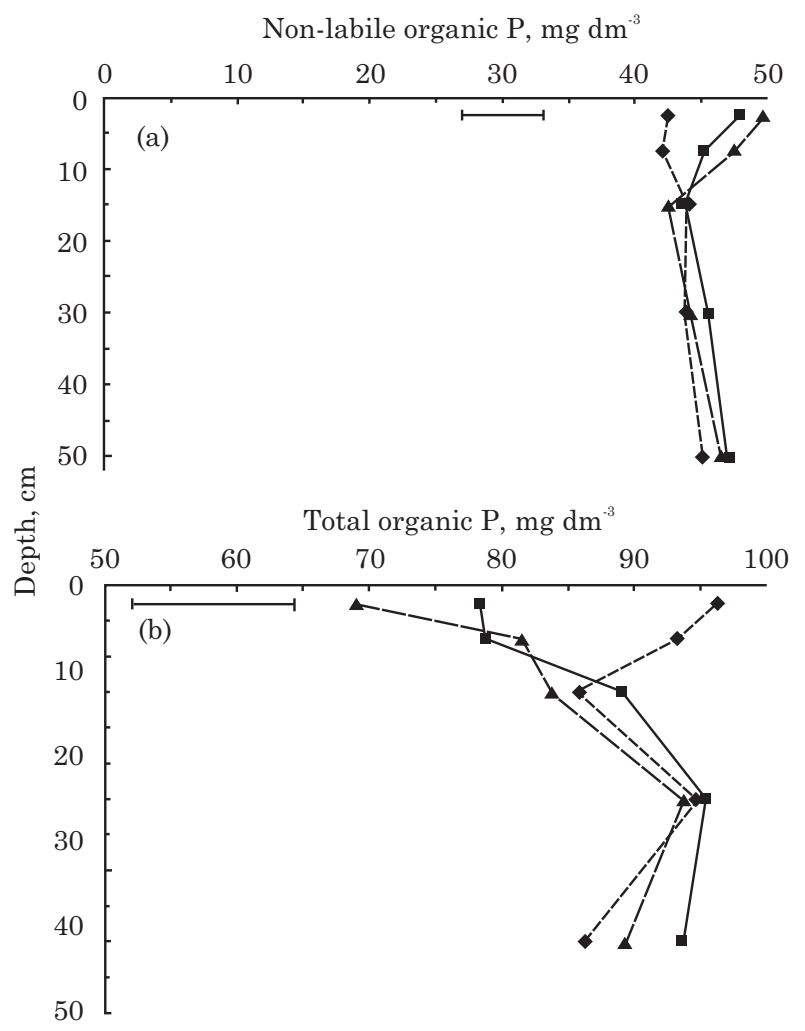

Figure 5. Non-labile and total soil organic $P$ in the soil profile as affected by surface- broadcast $P$ fertilizers. (a) Non-labile organic P; (b) Total organic P. Dotted line-No P; dashed line-natural reactive Arad phosphate; solid line - triple superphosphate. Horizontal bars show LSD $(p<0.05)$ and compare treatments within each soil depth.

2002; Silva et al., 2003). Accumulation of organic labile $\mathrm{P}$ in the uppermost soil layers (Figure $4 \mathrm{a}$ ) can be a result of $\mathrm{P}$ accumulated on the soil surface from plant residues. According to Silva et al. (2003), the use of Brachiaria sp as a cover crop led to the accumulation of organic $\mathrm{P}$ forms in the soil. They also reported that the low inorganic labile $\mathrm{P}$ levels found in the soil after Brachiaria sp were due to the extraction of labile $\mathrm{P}$ by the plant, and the return of this nutrient to the soil as organic labile P. Therefore, plants take up soil inorganic $\mathrm{P}$ forms that are more labile, and this $\mathrm{P}$ returns to soil in organic forms. Both processes favor the accumulation of organic $\mathrm{P}$ forms in the profile, even when no fertilizer is applied. In the long run, plants can use $\mathrm{P}$ from organic sources almost as efficiently as those from mineral sources due to organic P hydrolysis, releasing inorganic P (Tarafdar \& Claassen, 1988). Organic P from the soil can act as source or sink for the available $\mathrm{P}$, depending on soil management and fertilization (Novais \& Smyth, 1999). The increased $P$ availability in the uppermost soil layers under no-till may lead to a higher conversion of Pi into Po (organic P). 

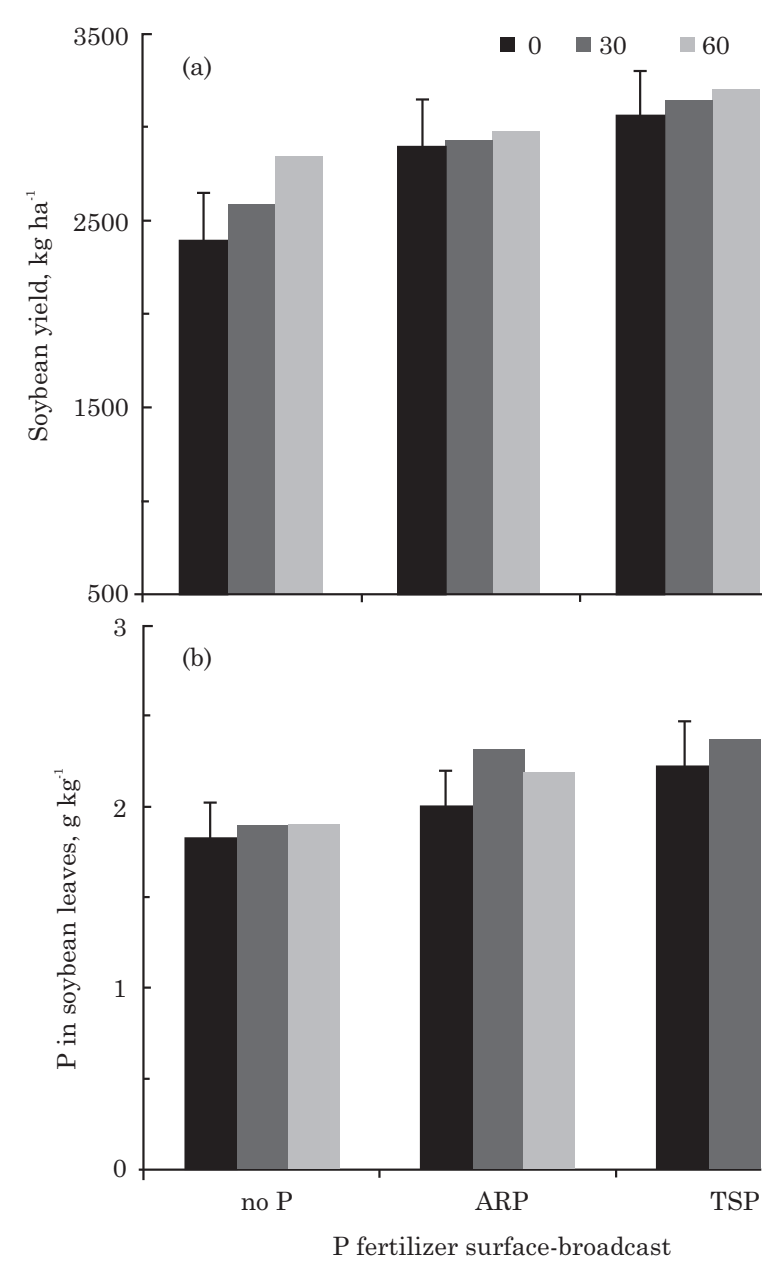

Figure 6. Soybean yields (a) and leaf $P$ concentrations (b) as affected by surface-broadcast and furrowapplied $\mathbf{P}$ fertilizers. no $\mathbf{P}$ - no $\mathbf{P}$ broadcast; ARP - $80 \mathrm{~kg} \mathrm{ha}-1$ of $\mathrm{P}_{2} \mathrm{O}_{5}$ as natural reactive Arad phosphate; TSP - $80 \mathrm{~kg} \mathrm{ha}^{-1}$ of $\mathrm{P}_{2} \mathrm{O}_{5}$ as triple superphosphate. Inserts 0,30 , and 60 represent $\mathrm{kg} \mathrm{ha}^{-1}$ of $\mathrm{P}_{2} \mathrm{O}_{5}$ applied to soybean furrows as TSP. Bars over the columns shows LSD $(p<0.05)$

The inorganic $\mathrm{Fe} / \mathrm{Al}$-bound $\mathrm{P}$ fraction extracted with $0.1 \mathrm{~mol} \mathrm{~L}^{-1} \mathrm{NaOH}$ was increased by P fertilization in the soil profile, and the soluble phosphate resulted in a greater increase (Figure $4 \mathrm{~b}$ ). In a similar experiment, Galvani et al. (2008) also found increased Fe-bound $\mathrm{P}$ in the soil profile when soybean was grown in rotation with pearl millet and triticale. After several years of cropping, $\mathrm{P}$ must have been released in the soil profile following root decay, and then it would be bound to $\mathrm{Fe}$ and $\mathrm{Al}$, considering that $\mathrm{pH}$ was lower at this soil depth (Table 1). This is consistent with a higher availability in deeper layers with a soluble $\mathrm{P}$ source because this would result in more roots (Rosolem et al., 1999). The $\mathrm{P}$ applied accumulates in inorganic fractions extracted by $\mathrm{NaHCO}_{3}$ and $0.1 \mathrm{~mol} \mathrm{~L}^{-1} \mathrm{NaOH}$, showing that a large proportion of $\mathrm{P}$ added as fertilizer is adsorbed and remains in moderately labile fractions (Pavinato et al., 2009).
Higher values of $\mathrm{Ca}$-bound and non-labile inorganic $\mathrm{P}$ (Figure 2) were determined when natural phosphate was used. This fact can be partially explained considering the higher $\mathrm{Ca}$ level in Arad phosphate $\left(264 \mathrm{~g} \mathrm{~kg}^{-1}\right)$ compared with TSP $\left(92 \mathrm{~g} \mathrm{~kg}^{-1}\right)$, which may foster the formation of Ca-P. One hypothesis to explain the increase of non-labile $\mathrm{P}$ in the soil profile is that the part of this less-available $\mathrm{P}$ not absorbed by plants could be washed down the soil profile through biopores left by decaying roots, and then be bound to soil colloids as a result of the lower soil $\mathrm{pH}$ deep in the soil. Kunishi et al. (1982) also observed that P added to the surface remained as Ca phosphate and was less adsorbed by colloids of the soil under no-till for three years.

The residual $\mathrm{P}$ fraction consists of inorganic and organic forms exhibiting high recalcitrance that usually do not participate actively in the $\mathrm{P}$ pool available to plants (Stewart \& Sharpley, 1987), although some authors have reported that this fraction can be a $\mathrm{P}$ source to plants in P-deficient systems (Guo, 2000). In the present study, there were no alterations in the residual $\mathrm{P}$ fraction (Figure 5a). This shows that residual $\mathrm{P}$ was preserved, whereas those forms presenting intermediate lability are capable of replacing more labile types. Similar results were obtained by Pavinato et al. (2009), who did not observe alterations in the residual $\mathrm{P}$ fraction.

There was an increase in total inorganic $\mathrm{P}$ down to the 40-60 $\mathrm{cm}$ depth with phosphate application (Figure $3 b$ ). In conservation tillage systems, total $\mathrm{P}$ levels usually increase over time, which favors nutrient cycling, increasing microorganism activity and, consequently, organic $\mathrm{P}$ mineralization. Pavinato et al. (2009) observed that phosphate fertilization results in $\mathrm{P}$ accumulation in less available fractions in the soil, leaving $\mathrm{P}$ in the soil after crop harvest. Eventually this $\mathrm{P}$ could migrate to more labile fractions and be available to crops grown in succession.

The readily available organic $\mathrm{P}$ was not affected by $\mathrm{P}$ fertilizations; however, the increased $\mathrm{Fe} / \mathrm{Al}$-bound and non-labile organic P (Figure 4 and 5a) can be understood taking into account that soils under notill have a repeated deposition of crop root residues that can return organic $\mathrm{P}$ to the soil during their decomposition. The absence of this effect in the deeper soil layer may be due to lower microorganism activity, since oxygen availability is lower.

The higher total soil organic $\mathrm{P}$ with ARP was unexpected (Figure 5b). Organic Fe/Al-bound and nonlabile organic $\mathrm{P}$ were higher with $\mathrm{P}$ fertilization, but did not differ between $\mathrm{P}$ sources, which do not explain this result.

There was no difference between $\mathrm{P}$ sources in soybean yields (Figure 6a). After several years and three applications of phosphates to the soil surface, there was enough time for the fertilizers to dissolve and be distributed throughout the soil profile due to root exudates, low weight organic acids, and biological 
activity (Pavinato \& Rosolem, 2008). Soybean responded to surface-broadcast $\mathrm{P}$ when there was no $\mathrm{P}$ applied in the seed furrow, showing a residual effect of the fertilizer. Broadcast $\mathrm{P}$ on the soil surface, in the long run, may be an effective way to manage phosphate fertilization for soybean under no-till. However, yields were similar when lower rates of $\mathrm{P}$ were used in the planting furrows.

\section{CONCLUSIONS}

1. Surface-broadcast fertilizers increase soil readily-available $\mathrm{P}$ down to the $0-10 \mathrm{~cm}$ depth, and less-available $\mathrm{P}$, both organic and inorganic, in the soil profile, indicating that this $\mathrm{P}$ may be available eventually, irrespective of the $\mathrm{P}$ source.

2. Despite soybean response to TSP and ARP broadcast on the soil surface, lower $\mathrm{P}$ rates of soluble $\mathrm{P}$ applied to the seed furrow are effective in supplying $\mathrm{P}$ to soybean.

3. Phosphorus fertilizer should be applied as a starter fertilizer even when the soil has received accumulated $\mathrm{P}$ fertilizations.

\section{LITERATURE CITED}

CONDRON, L.M.; GOH, K.M. \& NEWMAN, R.H. Nature and distribution of soil phosphorus as revealed by a sequential extraction method followed by ${ }^{31} \mathrm{P}$ nuclear magnetic resonance analysis. J. Soil Sci., 36:199-207, 1985.

DOBERMANN, A.; GEORGE, T. \& THEWS, N. Phosphorus fertilizer effects on soil phosphorus pools in acid upland soils. Soil Sci. Soc. Am. J., 66:652-660, 2002.

ERICH, M.S.; FITZGERALD, C.B. \& PORTER, G.A. The effect of organic amendments on phosphorus chemistry in a potato cropping system. Agric. Ecosyst. Environ., 88:7988, 2002.

FEHR, W.R.; CAVINESS, C.E.; BURMOOD, D.T. \& PENNINGTON, J.S. Stage of development descriptions for soybeans, Glycine $\max$ (L.) Merrill. Crop Sci., 11:929993, 1971.

FRANCISCO, E.A.B.; CÂMARA, G.M.S. \& SEGATELLI, C.R. Estado nutricional e produção do capim-pé-de-galinha e da soja cultivada em sucessão em sistema antecipado de adubação. Bragantia, 66:259-266, 2007.

GALVANI, R.; HOTTA, L.F.K. \& ROSOLEM, C.A. Phosphorus sources and fractions in an Oxisol under no-tilled soybean. Sci. Agric., 65:415-421, 2008.

GARCIA, R. Culturas forrageiras usadas em integração lavoura-pecuária. In: ZAMBOLIM, L.; SILVA, A.A. \& AGNES, E.L., eds. Manejo integrado: Integração lavourapecuária. Viçosa, MG, Universidade Federal de Viçosa, 2004. p.331-352.
GUO, F. Changes in phosphorus fractions under intensive plant growth. Soil Sci. Soc. Am. J., 64:681-1689, 2000.

HEDLEY, M.J.; J STEWART, W.B. \& CHAUHAN, B.S. Changes in inorganic and organic soil phosphorus fractions induced by cultivation practices and by laboratory incubations. Soil Sci. Soc. Am. J., 46:970-976, 1982.

HOROWITZ, N. \& MEURER, E.J. Eficiência agronômica de fosfatos naturais. In: YAMADA, T. \& ABDALLA, S.R.S., eds. Fósforo na agricultura brasileira. 2ed. Piracicaba, Potafos, 2004. p.665-668.

KUNISHI, H.M.; BANDEL, V.A. \& MULFORD, F.R. Measurement of available soil phosphorus under conventional and no-till management. Commun. Soil Sci. Plant Anal., 13:607-618, 1982.

MURPHY, J. \& RILEY, J.P. A modified single method for determination of phosphates in natural waters. Anal. Chim. Acta, 27:31-36, 1962.

NOVAIS, R.F. \& SMYTH, T.J. Fósforo no solo e planta em condições tropicais. Viçosa, MG, Universidade Federal de Viçosa, 1999. 399p.

OLIBONE, D. \& ROSOLEM, C.A. Phosphate fertilization and phosphorus forms in an Oxisol under no-till. Sci. Agric., 67:465-471, 2010.

OLSEN, S.R. \& SOMMERS, L.E. Phosphorus, In: PAGE, A.L.; MILLER, R.H. \& KEENEY, Q.R., eds. Methods of soil analysis: Chemical and microbiological properties. 2.ed. Madison, Soil Science Society of America, 1982. Part 2. p.403-430.

PAVINATO, P.S. \& ROSOLEM, C.A. Disponibilidade de nutrientes no solo-decomposição e liberação de compostos orgânicos de resíduos vegetais. R. Bras. Ci. Solo, 32:911-920, 2008.

PAVINATO, P.S.; MERLIN, A. \& ROSOLEM, C.A. Phosphorus fractions in Brazilian Cerrado soils as affected by tillage. Soil Till. Res., 5:149-155, 2009.

PEARSE, S.J.; VENEKLAAS, E.; CAWTHAY, G.; BOLLAND, M. \& LAMBERS, H. Carboxylate release of wheat, canola and 11 grain legume species as affected by phosphorus status. Plant Soil, 288:127-139, 2006.

RAIJ, B.van; ANDRADE, J.C.; CANTARELLA, H. \& QUAGGIO, J.A. Análise química para avaliação da fertilidade de solos tropicais. Campinas, Instituto Agronômico, 2001. 285p.

RHEINHEIMER, D.S.; ANGHINONI, I. \& KAMINSKI, J. Depleção de fósforo inorgânico de diferentes frações provocadas pela extração sucessiva com resina em diferentes solos e manejos. R. Bras. Ci. Solo, 24:345-354, 2000.

SAS Institute. SAS user's guide: Statistics, Version 8.2. Cary, 2001.

SOIL SURVEY STAF. Keys to soil taxonomy. 11.ed. Washington, USDA//NRCS, 2010.

ROSOLEM, C.A.; WITACKER, J.P.T.; VANZOLINI S. \& RAMOS, V.J. The significance of root growth on cotton nutrition in an acid low-P soil. Plant Soil, 212:185-190, 1999.

SILVA, M.A.; NOBREGA, J.C.A.; CURI, N. \& SIQUEIRA, J.O. Frações de fósforo em Latossolos. Pesq. Agropec. Bras., 38:1197-1207, 2003. 
STEWART, J.W.B. \& SHARPLEY, A.N. Controls on dynamics of soil and fertilizer phosphorus and sulfur. In: FOLLETT, R.F., ed. Soil fertility and organic matter as critical components of production systems. 4.ed. Madison, Soil Science Society of America, 1987. p.101-121.
TARAFDAR, J.C. \& CLAASSEN, N. Organic phosphorus compounds as a phosphorus source for higher plants through the activity of phosphatases produced by plant roots and microorganisms. Biol. Fert. Soils, 5:308-312, 1998. 